\title{
In vitro CULTURE OF FISH LOUSE (Lepeoptheirus salmonis) IN ATLANTIC SALMON (Salmo salar L. ) HOST CELL LINE
}

\section{Chandravathany Devadason*\#}

Department of Cell Biology and Molecular Biology, Marischal College, University of Aberdeen, UK

Received - November 10, 2017; Revision - April 21, 2018; Accepted - June 05, 2018

Available Online - June 20, 2018

DOI: http://dx.doi.org/10.18006/2018.6(3).617.622

\section{KEYWORDS}

In vitro culture

Chalimus

Copepodid

Cell line

Survival

Attachment

\begin{abstract}
The salmon louse (Lepeophtherius salmonis), is a crustacean ectoparasite of salmonids and causes significant economical losses in Atlantic salmon farms. The aim of this study was establishing the in vitro culture and explants of infective stage of L.salmoins. The skin epithelial cell line of the Atlantic salmon was made and the sterilized chalimus stage was added for attachment. An experimentally was tried to produce the cell culture of the chalimus using growth medium. Chalimus attachment on Atlantic salmon fibroblast and epithelial cell line was observed. The supernatant which was collected from the chalimus attached wells screened by using SDS-PAGE, showed the protein $(60 \mathrm{kd})$ band which have been not reported in control without chalimus attached. The chalimus attachment was observed in ASEW cell line but not CHSE-214 and RTG cell line which showed that Atlantic salmon was more susceptible for L. salmonis infection and this infection was species specific. The chalimus cell culture showed no growth in the growth medium used. This study presents a novel approach to cultivate the infective stages of sea lice, the copepod did and the attached stage, the chalimus in vitro.
\end{abstract}

* Corresponding author

\#Present address: Department of Zoology, Eastern University, Sri Lanka, Chenkalady, 30350 E-mail: chand_oo@yahoo.com (Chandravathany Devadason)

Peer review under responsibility of Journal of Experimental Biology and Agricultural Sciences.

Production and Hosting by Horizon Publisher India [HPI] (http://www.horizonpublisherindia.in/).

All rights reserved.
All the article published by Journal of Experimental Biology and Agricultural Sciences is licensed under a Creative Commons Attribution-NonCommercial 4.0 International License Based on a work at www.jebas.org.

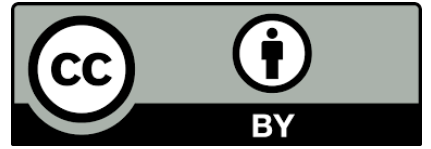




\section{Introduction}

The farmed salmon industry has grown substantially in the past 40 years and today approximately $60 \%$ of the world's salmon production is farmed and rest from wild (Ellis et al., 2016). The Atlantic salmons are most susceptible to Lepeophtherius infection as compared to other salmon species (Johnson \& Albright, 1992). The salmon louse, Lepeopththirus salmonis L, is a crustacean ectoparasite of salmonids and causes significant economic losses in salmon farms (Pike,1989). Parasites have complex lifecycle and have different defense strategies (either as secretory or structural) to survive successfully in host cells (Schmid-Hempe, 2009). Cell culture is generally considered as useful technique for biochemical and immunological studies (Arasu et al. 2014). The development of in vitro culture utilizing tissues from shrimp species (Jayesh et al. 2013), Lepidopteran and dipteran insect culture (Lee \& Hou, 1992) and tick culture (Munderloh et al., 1994). Most in vitro culture has been performed with protozoan (Visvesvara \& Garcia, 2002) and helminthes parasites, Schistosoma mansoni (Bayne et al., 1994). The host signals for the attachment of various ecto and endoparasites in host explant have been well studied in fish parasitic copepodid (Salmonicola edwardsii), cercaria of the fish parasite (Acanthosstomum japanicum), duck parasite (Trichobilharzia ocellate) and the human parasite (Schistosoma japanicum). The primary culture of normal pituitary cells of carp (Cyprinus carpio) released gonadropin during in vitro culture (Ribeiro et al., 1983). Similarly, synthesis of Sarcophaga lectin and sarcotoxins in NIHSAPE-4 from the Sarcophaga peregrine embryonic cell line was also reported by the Komano et al. (1988). The parasitic adhesions on host surfaces have been widely employed in mammalian cell lines (Lumb et al., 1988). Primary cell cultures and immortal cell lines have been developed from Toxoplasma gondii (Wang, 1970; Hughes et al., 1986) and its growth in ovine fetal kidney cell culture has been evaluated (Liu et al., 2016; Chang \& Gabrielsom, 1984). Peneration of Schistosoma mansoni cercaria into a living skin equivalent host materials has been described by Ingram et al. (2003). Till now, the signal for the attachment of L. salmonis to Atlantic salmon skin is not studied and the present study evaluate the in vitro attachment of L. salmonis to skin explants and epithelial cell mono layers which will be useful in understanding signal mechanism of L. salmonis.

\section{Materials and Methods}

\subsection{Collection of Egg-Strings of Salmon Lice}

Gravid females with egg strings were collected from Atlantic salmon (Salmo salar L), in fish farms on west coast of Scotland and were transported to the Laboratory in iced sea water. The samples were examined using a microscope to confirm the presence of copepod parasites L. salmonis.

\subsection{Culture of Copepodids}

Mature egg-strings were dissected from the adult female lice and cultured in a glass beaker containing 3 liters of double filtered fresh water with an osmolarity of $754 \mathrm{mmol} / \mathrm{kg}$ and $7.6 \mathrm{pH}$. The eggs were maintained at $5^{0} \mathrm{C}$ with continuous aeration at $12 \mathrm{hrs}$ photoperiod until the Nauplius stages were observed. The water was changed at every $12 \mathrm{hrs}$ intervals by using a nylon net and other debris were removed daily. The newly hatched naupli were captured using a $100 \mu \mathrm{m}$ nitex filter and transferred to a second beaker containing fresh double filtered sea water under the same conditions. An inverted binocular microscope was used to monitor the development of the nauplii into copepodids which were removed by filtration for further use.

\subsection{Culture of different host cell monolayers on a collagen matrix}

Atlantic salmon epithelial cell line (ASE-W) at passage number 148, was subcultured in the growth medium for ASE-W cell line, the media contained $76.7 \%(\mathrm{v} / \mathrm{v})$ of Glascow- minimum essential medium ( G-MEM), 10\% (v/V) Foetal bovine serum (FBS), 10\% (v/v) Tryptose phosphate broth (TPB), 1\% (v/v) Non-essential amino acid (NEAA), $1 \%(\mathrm{v} / \mathrm{v}) \mathrm{NaHCo}, 0.8 \%(\mathrm{v} / \mathrm{v})$ in $2 \mathrm{M}$ Tris buffer, $\mathrm{pH} 7.4$, and $0.5 \%$ (v/v) kanamysin. The stock collagen $(3 \mathrm{mg} / \mathrm{ml})$ was extracted from the thawed rat tail according to a method described by Strom \& Michalopoulos, (1982) and 7.5\% (v/v) of $5 \mathrm{M} \mathrm{NaHCO}_{3}, 2 \mathrm{ml}$ of $1 \mathrm{M} \mathrm{CaCl}_{2}$ and $2 \mathrm{ml}$ of $1 \mathrm{~m}$ of $\mathrm{mgCl} 2$ were added into the stock collagen. The volume and concentration of collagen that were required for optimal cell growth were optimized (see results for details). Briefly, the stock collagen solution was diluted 1:3, 1:4, 1:5, 1:6, 1:7, 1:8, 1:9 and 1:10 in double distilled water or in the growth medium. The varying volume of each diluted collagen was incorporated with $100 \mu$ l of growth medium containing $1 \times 10^{5}$ cells and dispensed into a 96 wells tissue culture plate (Nunc). The plate seeded with cells was incubated at $22^{\circ} \mathrm{C}$ in a cooled incubator. Once the confluent cell growth was observed by a microscope, it was ready for copepodid attachment assay.

\subsection{Copepodid invitro Attachment assay}

\subsubsection{Optimization of culture conditions}

The culture medium for copepodid attachment was optimized using the copepodid's survival which was determined how long it showed its activity and the cells viability which was determined with confluent cells spreading and appearance of cell in different medium with varying osmolarity. Mean copepodid survival percentage was calculated by using number of wells showed copepodid survival out of total wells that contained copepodids while mean survival of cells was calculated by calculating the 
cells with confluent cell monolayer while copepodid were in the wells. The media used were Minimum essential medium (MEM) (Gibco), Leibovitz (L-15) (Gibco), Sterile water, Phosphate buffered saline (PBS) and Insect medium (sigma) at $10^{\circ} \mathrm{C}$. Sterilization procedure for the copepodid was conducted prior to carrying out the in vitro attachment assay. Copepodids were harvested and surface sterilisation was carried out by washing the copepodids 3 times with sterile culture medium (MEM). Following this, the copepodids were incubated in sterile culture medium (MEM) containing gentamicin (10000units $/ \mathrm{ml}$ ) penicillin-streptomycin (1000units $/ \mathrm{ml}$ ), and amphitericin (1000units /ml) (Sigma) for $3 \mathrm{hrs}$ at $18^{\circ} \mathrm{C}$ in aseptic conditions.

A tissue culture plate that contained confluent cell monolayers on the collagen matrix was prepared as described above. MEM $(150 \mu 1,550 \mathrm{mml} / \mathrm{kg})$ was added into each well. The active sterilized copepodids were then picked up using a pipette and two copepodids per well were transferred into the culture medium and incubated at $10^{\circ} \mathrm{C}$ in a cooled incubator (Thermofisher Scientific ,UK) for attachment. Observation was carried out at $12 \mathrm{hrs}$ intervals and attachment was recorded using photography. The culture medium was replaced with fresh medium every $48 \mathrm{hrs}$, care being taken not to disturb the copepodids or cell layer.

\section{Results and Discussion}

\subsection{Copepodid attachment and chalimus growth}

Lepeopththerius salmonis growth and survival was high in medium with high osmolarity (Table 1 ). The infection of $L$. samoniswas reported in present study suggested that the chalimus, the initial attachment stage of salmon lice, can be cultivated in vitro. Copepodid attachment and its continuous growth were successfully achieved using Atlantic salmon epithelial cell line (ASE-W) and Atlantic salmon skin explant. Following settlement of the copepodids, filament ejection was observed, rapidly followed by the moult to first chalimus stage as judged by the appearance of ultrastructural studies of the attachment and development of copepodid described by Bron et al. (1991) and also appeared that filament possess a central duct seems to originate from the filamental socket that is located at the base of the cephalic region as described by Bron et al. (1991) and Pike et al. (1993). Further, as suggested by Johnson \& Albright (1992), during the copepodid attachment process, it releases glue like secretion which is thought to be injected beneath the epidermis where it spreads laterally along the basement membrane. So this glue like secretion may be released due to the rhythmic up and down movement of the uropods as observed in the present study when the copepod tries to attach to the skin tissue or cell monolayer and this movement can give a positive propulsive force which may help to penetrate the skin. As suggested by Norrby (1971) when copepodid invades in the host tissue, it secretes an enzyme that may be used for digestion of host's tissue and will help in penetration. Following attachment of the chalimus to the cell monolayer, the cell layer showed disappearance around the chalimus suggesting that chalimus grazed the cells as described in electron microscopic studies of chalimus food and feeding habits by Bron (1996) (Figure 2). During the attachment process, copepodids used their antenna and paired maxillipeds which pointed forward and could be seen in the dorsal view when they creep on the surface first before they attach to the host's skin ( ASE-W) cell line as this observation has already been pointed out by Bron et al. (1991). The number of survived chalimus in Atlantic cell line was high than CHSE cellline which indicates the Atlantic salmon cells are more susceptible for attachment of chalimus (Figure 3). However, Chalimus did not survive for a long period, probably, because the adhered skin tissue began to show the vacuolation inside the cytoplasm and nucleus. It was therefore suggested that the maintenance of the integrity of the Atlantic salmon skin explant or cell line is prime importance for the long term cultivation of the larval stages of sea lice.

Table 1 Cell and copepodid mean survival (\%) in two different osmolarities ( $\mathrm{mmol} / \mathrm{kg})$.

\begin{tabular}{|lcccccc|}
\multicolumn{1}{|c}{ Medium } & MEM & L-15 & PBS & Sea water & D H $\mathrm{H}_{2}$ Insect & $\begin{array}{c}\text { Inedium } \\
\text { medium }\end{array}$ \\
\hline Osmolarity I (mmol/kg) & 304 & 359 & 323 & 750 & 213 & 323 \\
\hline Copepodid Mean survival(\%) & 70.5 & 78.2 & 50.42 & 100 & 00 & 40.15 \\
\hline ASEcell Mean survival (\%) & 100 & 100 & 70 & 00 & 40 & 50 \\
\hline OsmolarityII (mmol/kg) & 550 & 500 & 510 & 750 & 100 & 532 \\
\hline Copepodid Mean survival(\%) & 80.12 & 70.1 & 30.4 & 10 & 20.3 \\
\hline ASE cell Mean survival (\%) & 100 & 70 & 10 & 00 & 00 & 00 \\
\hline
\end{tabular}

Journal of Experimental Biology and Agricultural Sciences http://www.jebas.org 


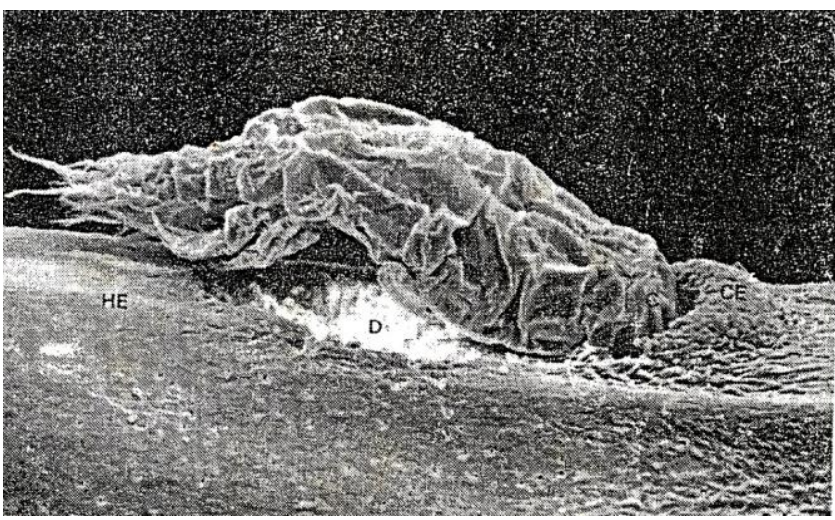

Figure 1 Adult stage of L. salmonis attached to the skin of Atlantic salmon. (Source from Bron et al., 1991)

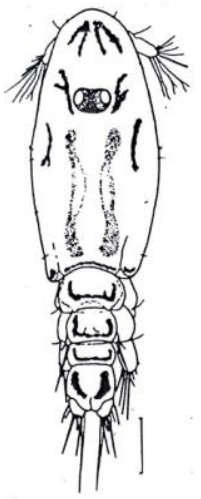

A

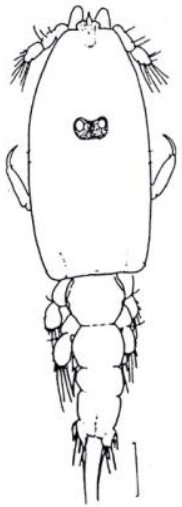

B
Figure 2 schematic 1llustration of Copepodid. A- tree living stage of copepodid, B-attached copepodid

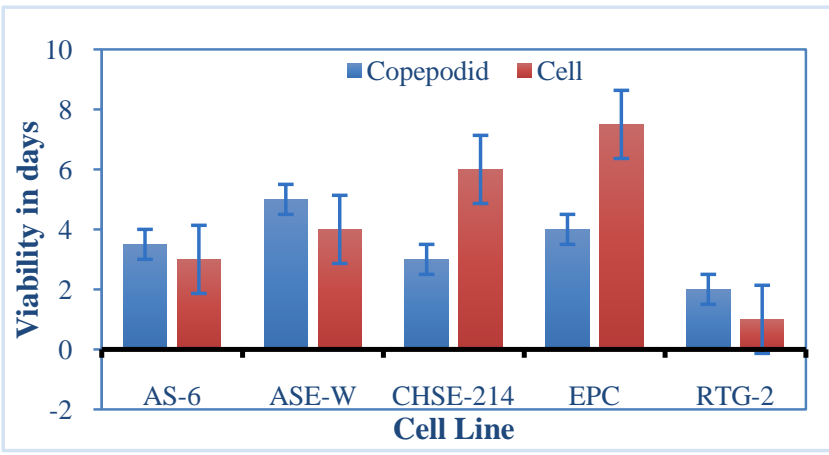

Figure 3 Optimal host cell monolayer for copepodid attachment. Here, AS-6 -Atlantic salmon fibroblast cell line, ASE-W-Atlantic salmon epithelial cell line, CHSE 214- Chinook salmon epithelial cell line, EPC-Epithelial papilloma cell line and RTG-2- Rainbowtrout gonad cell line. Data represented as mean $\pm \mathrm{SE}$
As far as the copepodid attachment in cell monolayer and skin explant are concerned, copepodid attachment and following moulting process were observed within $12 \mathrm{hrs}$ of incubation with the Atlantic salmon skin explant and this reflects that a chemical or mechanical stimulus may be given by the appropriate host surface that can be necessary to trigger for attachment and development. Attachment behavior was slightly different in host cell line from the host skin explant, suggesting that Atlantic epithelial cell line might have lack of specific host stimulus. The medium was MEM which gave greater survival of attached stages (Figure 1). In addition, copepodid showed the preference to attaching in Atlantic salmon epithelial cell line (ASE-W) rather than other salmonids cell line suggesting that copepodid stage of L.salmoins possess host specificity. As suggested by the results of study cercaria larvae of Acanthostomium brauni uses two chemical signals viz., free fatty acids and macromolecular mucus component (Haas \& deNunez, 1988; Haas, 1992) when they identifies their fish host whereas Motzel \& Haas (1985) reported that Isthio phoramelis used carbondioxide $\left(\mathrm{CO}_{2}\right)$ gas as the main host signal to attach to the host. Since there is lack of biochemical information in relation to copepodid attachment, only it is likely be accepted that copepodid can utilize the host skin lipid or its secretory product as suggested by Stirewalt (1974) who mentioned that the penetration of mammalian skin by Schistosome cercariae is limited by the surface lipids of the host. It is also reported that among the skin surface lipids, free fatty acids, especially polyunsaturated fatty acid, appears to be most efficacious in stimulating penetration (Austin et al., 1972). Fusco et al., (1985) concluded that the formation of eicosanoids is an essential step in the penetration of human skin by cercaria of Schistosoma mansoni and this process accomplished by vasodilation, which is induced by certain PGs, may help the parasite in finding the host. In addition, tick (Ixodes dammini) contains immunosuppressive compounds which facilitate blood feeding in the tick during prolonged period of host attachment ( Ribeiro et al.,1985). Titus et al. (1988) mentioned anti-inflammatory effect in the Leismaniasis infection when sand fly saliva mixed with Leismania major. So, it may be likely to be accepted that copepodid's secretory product or the host's skin lipid which may be metabolized into eicosanoids by the copepodid if some eicosanoids are suggested as inflammatory inhibitory agents (Ward, 1983).

An in vitro culture system has the potential of allowing the collection of excretory /secretory products, and would permit in vitro studies to be carried on larvae without unidentified media components, providing information on the mechanism of moulting and lack of an apparent host response, E/S products harvested when the chalimus attaches to host cell line 


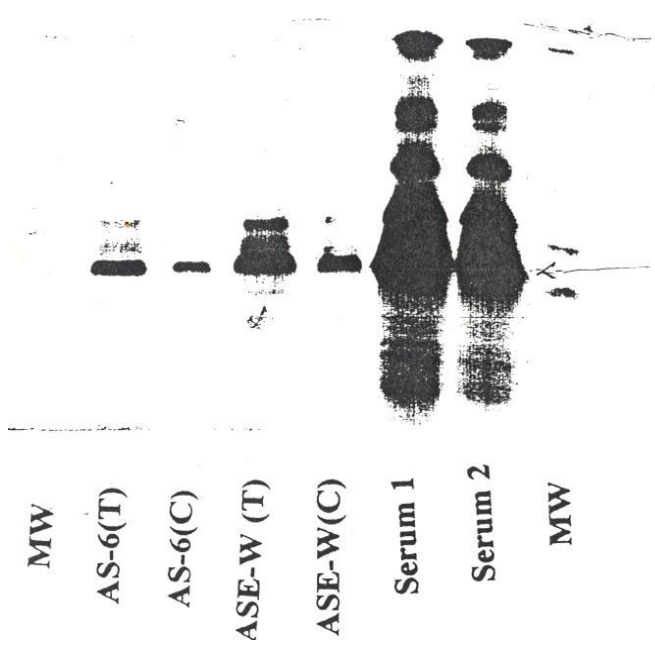

Figure 4 Electrophoretic separation using SDS-PAGE gel of the derived chalimus (L.salmonis) supernatant. MW- molecular weight, AS-6 (T)- Atlantic salmon fibroblast cell line and chalimus, AS-6 (CAtlantic fibroblast cell line with out chalimus, ASE-W(T)- Atlantic salmon epithelial cell line with chalimus, ASE-W@- Atlantic salmon epithelial cell line without chalimus, Serum 1 and 2- Atlantic salmon serum.

or explant could be used to evaluate the effect of the secretory substance of the chalimus on the hosts immune system. The SDSPAGE gel showed the $60 \mathrm{KD}$ protein band which should be excreted from the host parasite interaction and it can be suggested that ES product can be potentially important in the development of potential vaccine antigens or possible chemotherapeutic agents to control sea lice infection (Figure 4). As the main target is to maintain the cell line or skin explant in viable condition as long as chalimus moult into pre-adult, in vitro culture that was presently established needs to be improved with technical facilities. The cell line was established is used for further attachment of chalimus stages and also for study of immunological interaction between parasite and host.

\section{Conflict of Interest}

Authors would hereby like to declare that there is no conflict of interests that could possibly arise.

\section{References}

Arasu A, Kumaresan V, Sathyamoorthi A, Chaurasia MK, Bhatt P, Gnanam AJ, Palanisamy R, Marimuthu K, Pasupuleti M, Arockiaraj J (2014) Molecular characterization of a novel prototype antimicrobial protein galectin-1 from striped murrel. Microbiological Research 169 : 824-834. DOI: https://doi.org/10.1016/j.micres.2014.03.005.
Austin FG, Stirewalt MA, Danzinger R ( 1972) Schistosoma mansoni: stimulatory effect of rat skin lipid fractions on cercarial penetration behavior. Experimental Parasitology 31: 217-224.

Bayne CH, Meino JS, Hobbs D, Barnes DW (1994) In vitro Cultivation of Cells from Larval Schistosoma mansoni. Journal of Parasitology 80:29-35. DOI10.2307/3283341.

Bron J (1996) Ultrastructure, Physiology and endocrinology of sea lice. Aquaculture, University of Stirling 18.

Bron JE, Sommerville C, Jones M, Rae GH (1991) The settlement and attachment of early stages of the salmon louse, Lepeophtheriuos samlonis (Copepod: Caligidae) on the Salmon host, Salmo salar. Journal of Fish Diseases 224 : 201-212.

Chang G, Gabrielson DA(1984) Toxoplasma gondii: Growth in ovine fetal kidney cell cultures. Experimental Parasitology 57: 81-85.

Ellis T, Turnbul JF, Knowle TG, Line JA, Auchterlonie NA (2016) Trends during development of Scottish salmon farming: An example of sustainable intensification? Aquaculture 458: DOI: https://doi.org/10.1016/j.aquaculture.2016.02.012.

Fusco AC, Salafsky B, Delbrook K (1985) Schistosoma mansoni , Penetration of cercarial eicosanoids as correlates of penetration and transformation. Journal of Parasitology 79: 444-448.

Haas W (1992) Physiological analysis of cercarial behaviour. Journal of Parasotiology78: 243-255.

Haas W, de Nunez MO(1988) Chemical signals of fish skin for the attachment response of Acanthos stomumbrauni cercariae. Parasitiology Research 74: 552-557.

Hughes HP, Hudson L, Fleck DG (1986) In vitro culture of Toxoplasma gondii in primary and established cell lines. International Journal of Parasitology 4: 317-322

Ingram RJ, Bartlett A, Brown MB Marriott C, Whitfield PJ (2003) Penetration of human skin by the cercariae of Schistosoma mansoni: an investigation of the effect of multiple cercarial applications. Journal of Helminthology 77: 27-31 DOI: $10.1079 / \mathrm{JOH} 2002157$.

Jayesh P, Jose S, Philip R, Bright Singh IS (2013) A novel medium for the development of in vitro cell culture system from Penaeus monodon. Cytotechnology 65 : 307-322.

Johnson SC, Albright LJ (1992) Comparative susceptibility and histopathology of the response of naïve Atlantic, Chinook and Coho salmon to experimental infection with Lepeophtherius 
salmonis ( Cpepoda: Caligidae). Diseases of Aquatic Organisms 14: 179-193.

Komano H, Kasama E, Nakanishi Y, Matsuyama K, Ando K, Nagasawa Y, Natori S (1988) Synthesis of Sarcophaga lectin and sarcotoxins in NIH-SAPE-4, an embryonic cell line of Sarcophaga peregrine. In: Kuroda Y, Kurstak E, Maramorosch K (Eds) Invertebrate and Fish Tissue culture, Japan Societies Press, Tokyo 75-78.

Lee H, Hou RF (1992) Establishment of a cell line derived from embryos of the diamond back moth, Plutella xylostella (L). Journal of Invertebrate Pathology 59: 174-177.

Liu L, Wang J, Duan S, Chen L, Xiang H, Dong Y, Wang W (2016) Systematic evaluation of sericin protein as a substitute for fetal bovine serum in cell culture. Science Reports 6: 315-316. DOI: $10.1038 /$ srep31516.

Lumb R, Smith K, O’Donoghue, Lanser LA (1988) Ultrastructure of the attachement of Cryptosporium sporozoites to tissue culture cells. Parasitiology Research 74:531-536.

Motzel W, Haas W (1985) Studies on the attachment response of Isthmio phoramelis cercariae (Trematoda P: Echinostomatidae). Zeitchrift fur Parasitenkunde 71: 519-526.

Munderloh UG ,Liu Y, Wang M, Chen C, Kurtti TJ (1994) Establisment, maintenance and describtion of cell lines from the tick, Ixodesscapularis. Journal of Parasitiology 80: 533-543.

Norrby R (1971) Immunological study on the host cell penetration factor of Toxoplasma gondii. Infection and Immunity 3: 278-286.

Pike AW (1989) Sea Lice Major pathogens of farmed Atlantic salmon. Parasitiology Today 5 : 291-297.

Pike AW, Mackenzie, Rowand A (1993) Ultrastructure of the frontal filament in chalimus larvae of Caligus elongatus and Lepeopththeriussalmonis from Atlantic salmon, Salmo salar. In: Boxshall GA, Defaye D (Eds.) Pathogens of wild and farmed fish: sea lice, London, Ellis Horwood series in Aquaculture and Fisheries support, 100-113.

Ribeiro JMC, Makoul GT, Levine J, Robinson DR, Spielman A (1985) Antihemos taticanti inflammatroy and immunosuppressive properties of the saliva of atick, Ixodes dammini. Journal of Experimental Medicine 161:332-344.

Riberio LP, Ahne W, Lichtenberg V (1983) Primary culture of normal pituitary cells of carp (Cyprinus carpio) for the study of gonadotropin release. In Vitro $19: 41-45$. DOI 10.1007/BF02617992.

Schmid-Hempel P (2009) Immune defence, parasite evasion strategies and their relevance for 'macroscopic phenomena' such as virulence. Philosophical Transactions of the Royal Society of London. Series B - Biological Sciences 364 :85-98.

Stirwalt MA (1974) Schistosoma mansoni: cercaria to schistosomula. Advances in Parasitiology 12:115-182.

Titus RG, Riberio JM (1988) Salivary gland lysates from the sand fly Lutzomyia longipalpis enhance Leismania infectivity. Science 239: 1306-1308.

Visvesvara GS, Garcia LS (2002) Culture of Protozoan Parasites, Clinical Microbiological Review 15 : 327-328. doi: 10.1128/CMR.15.3.327-328.2002.

Wang CT (1970) Multiplication of Toxoplasma gondii in tissue cultures and its subsequent virulence in mice. Chinese Journal of Microbiology 3: 111-117.

Ward PA (1983) Immunology of Inflammation, In: BellantiJA (Ed), Immunology III, Amsterdam, Elsevier/North Holland. 